\title{
Molecular Detection and Phylogeny of Anaplasma phagocytophilum and Related Variants in Small Ruminants from Turkey
}

\author{
Münir Aktaş *Did, Sezayi Özübek and Mehmet Can Uluçeşme \\ Department of Parasitology, Faculty of Veterinary Medicine, University of Firat, 23119 Elazig, Turkey; \\ sozubek@firat.edu.tr (S.Ö.); mculucesme@firat.edu.tr (M.C.U.) \\ * Correspondence: maktas@firat.edu.tr; Tel.: +90-(424)-237-0000
}

Citation: Aktaş, M.; Özübek, S.; Uluçeşme, M.C. Molecular Detection and Phylogeny of Anaplasma phagocytophilum and Related Variants in Small Ruminants from Turkey. Animals 2021, 11, 814. https:// doi.org/10.3390/ani11030814

Academic Editor: Robert W. Li

Received: 25 February 2021

Accepted: 11 March 2021

Published: 14 March 2021

Publisher's Note: MDPI stays neutral with regard to jurisdictional claims in published maps and institutional affiliations.

Copyright: (c) 2021 by the authors. Licensee MDPI, Basel, Switzerland. This article is an open access article distributed under the terms and conditions of the Creative Commons Attribution (CC BY) license (https:// creativecommons.org/licenses/by/ $4.0 /)$.
Simple Summary: We explored the existence of Anaplasma phagocytophilum and related variant in samples of goats and sheep obtained from Antalya and Mersin provinces, representative of Mediterranean region of Turkey. Based on $16 S$ rRNA and groEL genes of A. phagocytophilum and related variants, we examined blood samples by polymerase chain reaction (PCR) followed by sequencing. The results showed that the prevalence of A. phagocytophilum and A. phagocytophilum-like 1 infection was $1.4 \%$ and $26.5 \%$, respectively. Sequencing confirmed molecular data and showed the presence of A. phagocytophilum and A. phagocytophilum-like-1 variant in the sampled animals.

Abstract: Anaplasma phagocytophilum causes tick-borne fever in small ruminants. Recently, novel Anaplasma variants related to A. phagocytophilum have been reported in ruminants from Tunisia, Italy, South Korea, Japan, and China. Based on $16 S$ rRNA and groEL genes and sequencing, we screened the frequency of $A$. phagocytophilum and related variants in 433 apparently healthy small ruminants in Turkey. Anaplasma spp. overall infection rates were 27.9\% (121/433 analyzed samples). The frequency of $A$. phagocytophilum and $A$. phagocytophilum-like 1 infections was $1.4 \%$ and $26.5 \%$, respectively. No $A$. phagocytophilum-like 2 was detected in the tested animals. The prevalence of Anaplasma spp. was comparable in species, and no significant difference was detected between sheep and goats, whereas the prevalence significantly increased with tick infestation. Sequencing confirmed PCR-RFLP data and showed the presence of A. phagocytophilum and A. phagocytophilum-like-1 variant in the sampled animals. Phylogeny-based on $16 S$ rRNA gene revealed the A. phagocytophilum-like 1 in a separate clade together with the previous isolates detected in small ruminants and ticks. In this work, A. phagocytophilum-like 1 has been detected for the first time in sheep and goats from Turkey. This finding revealed that the variant should be considered in the diagnosis of caprine and ovine anaplasmosis.

Keywords: tick-borne fever; Anaplasma phagocytophilum-like 1; PCR-RFLP; small ruminant

\section{Introduction}

Anaplasma phagocytophilum is the agent of tick-borne fever (TBF) or pasture fever, a disease affecting some species of domestic ruminants (cattle, sheep, goats). The bacterium is a pathogenic species for livestock such as ruminants as well as humans in temperate and tropical countries [1-4]. Anaplasma phagocytophilum is transmitted by Ixodes spp. and infects host neutrophils and monocytes, where reproduction occurs [1,5]. Anaplasma phagocytophilum infection is known as pasture fever and characterized by fever, anorexia, lateral recumbency, dullness, and loss of milk yield in affected hosts [2,4,6].

Increased attention to $A$. phagocytophilum reveals new information about the genetic diversity of the pathogen. Recently two Anaplasma variants related to A. phagocytophilum have been documented in cattle, sheep, goats, and ticks [7-9]. In Japan, A. phagocytophilum-like 1 has been detected in deer and Hemaphysalis longicornis [10], cattle [11], Ixodes spp. [12], and Haemaphysalis megaspinosa [13]. A. phagocytophilum-like 2 has been identified in Hyalomma 
asiaticum [14], sheep and goats from China [15]. Recently those Anaplasma variants have been documented in ruminants from Tunisia [7,8], South Korea [16], and Italy [17].

Various Anaplasma species including A. phagocytophilum have been documented in ruminants and ticks in Turkey [5,6,18-21]. However, until now no data on A. phagocytophilum variants is available in Turkey. In the current study, $16 \mathrm{~S}$ rRNA, groEL (heat shock protein) PCR and sequencing were performed to identity A. phagocytophilum and A. phagocytophilumlike variants in small ruminants from sampling sites in Antalya and Mersin provinces, where the representative Mediterranean area of Turkey.

\section{Materials and Methods}

\subsection{Study Region and Sample Collection}

This survey was conducted in small ruminants farmed in three districts (Alanya, Akseki, Manavgat) from Antalya (latitude $36^{\circ} 53^{\prime} \mathrm{N}$, longitude $30^{\circ} 42^{\prime} \mathrm{E}$ ) and two districts (Anamur, Bozyazi) from Mersin (latitude $36^{\circ} 47^{\prime} \mathrm{N}$, longitude $34^{\circ} 37^{\prime} \mathrm{E}$ ) provinces of Turkey (Figure 1). This area has a Mediterranean climate, with hot humid summers and warm rainy winters. The goats and sheep are kept in closed areas in villages near to the coast during the winter months, and they are taken to the plateaus in the Taurus Mountains in the early spring and grazed in the pastures here until autumn.

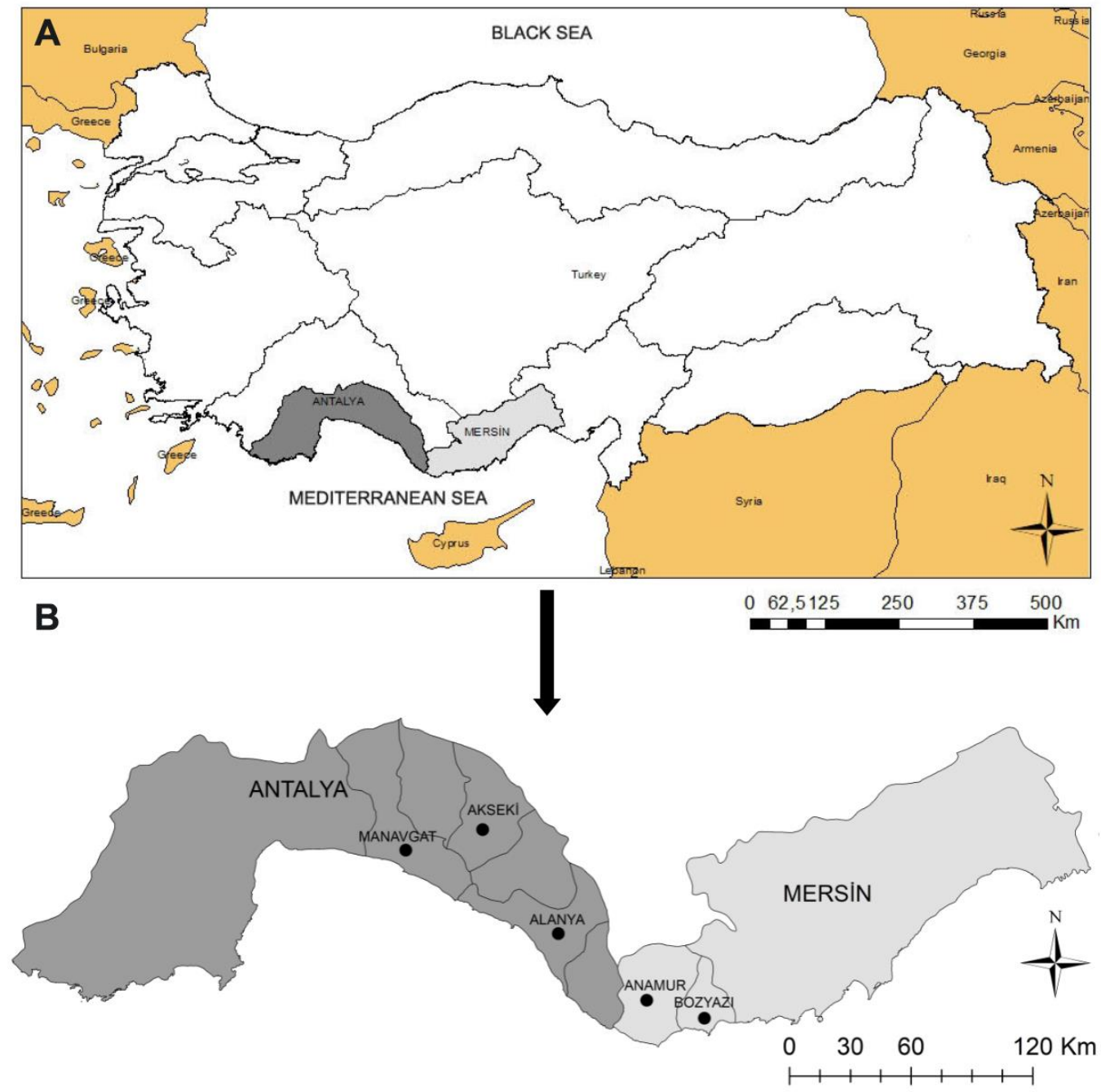

Figure 1. Map of Turkish provinces, indicating the localities studied in the study. (A) Geographical position of the provinces of Antalya and Mersin in Turkey. (B) Position of localities sampled in the provinces of Antalya and Mersin. 
The sample size was calculated using the online tool Sample Size Calculator (www. calculator.net/sample-sizecalculator.html, accessed on 1 February 2019), for a confidence level (CL) of 95\%, an error margin of 5\%. According to this, during April-July 2019, a total of 433 apparently healthy small ruminants (296 goats, 137 sheep) were included in the survey. Blood samples were drawn from the punctured jugular vein into anticoagulated (K3-EDTA) vacutainer tubes and stored at $-20^{\circ} \mathrm{C}$ freezer until DNA extraction. The goats and sheep were also checked for tick infestations, and a total of 1475 ticks were removed. The collected ticks were preserved in $70 \%$ ethanol in Eppendorf tubes. They were identified using taxonomic keys [22]. The animals were grouped into categories according to species (goat and sheep) and the presence of ticks (yes/no). This study secured the approval of the Elazig Veterinary Control Institute (number: 2018/02).

\subsection{DNA Extraction and Amplification of $16 S$ rRNA Gene}

DNA was isolated from $200 \mu \mathrm{L}$ volumes of whole blood using a DNAeasy Blood Minikit according to the vendor's recommendations. Genomic DNA from blood of clinically infected cattle with A. phagocytophilum [6] was used for positive control. Anaplasma phagocytophilum-like variants DNAs, received from Alberto Alberti (University of Sassari, Sassari, Italy) were used as positive controls.

To detect $A$. phagocytophilum and A. phagocytophilum-like variants, a nested 16S rRNA PCR was carried out described by Kawahara et al. [10]. The PCR reaction conditions were made according to the previously described studies $[10,21]$. The nested amplicons were examined by $1.5 \%$ agarose gel electrophoresis and visualized using the gel Documentation System (Vilber Lourmat, Marne La Vallee Ceedex, France).

\subsection{Restriction Fragment Length Polymorphism (RFLP)}

$X c m \mathrm{I}$ and $B s a \mathrm{I}$ restriction enzymes allow the specific discrimination amongst $A$. phagocytophilum and related variants $[8,17]$. For differentiation of A. phagocytophilum and related variants, the nested amplicons obtained in this study were digested with the XcmI and BsaI restriction enzymes as previously described $[8,17]$.

\subsection{GroEL PCR}

To confirm the results of the RFLP assay, the positive samples were screened by a groEL nested PCR for the amplification of A. phagocytophilum [23]. The semi-nested PCR reported by Ybañez et al. [24] with the primers EEGro1F/AnaGroe712R and AnaGroe240F was utilized for amplifying of $A$. phagocytophilum-like 1 groEL gene. Oligonucleotide primers used in this study were presented in Table 1.

Table 1. Oligonucleotide primers used in this study $\left({ }^{*}\right.$ Degenerate primer: $\mathrm{Y}=\mathrm{C}$ or $\left.\mathrm{T}\right)$.

\begin{tabular}{|c|c|c|c|c|c|c|}
\hline Target Gene & Specificity & Primer Name & Oligonucleotide Dequence $\left(5^{\prime}-3^{\prime}\right)$ & Annealing & $\begin{array}{l}\text { Amplicon } \\
\text { Size (bp) }\end{array}$ & Reference \\
\hline $\begin{array}{l}- \\
-\end{array}$ & $\begin{array}{c}\text { All } \\
\text { Anaplasma/Ehrlichia }\end{array}$ & $\begin{array}{l}\text { EC9 } \\
\text { EC12a }\end{array}$ & $\begin{array}{c}\text { TACCTTGTTACGACTT } \\
\text { TGATCCTGGCTCAGAACGAACG }\end{array}$ & 54 & 1462 & \multirow[b]{2}{*}{ [10] } \\
\hline $16 S r R N A$ & $\begin{array}{l}\text { - } \\
\text { A. phagocytophilum } \\
\text { and related variants }\end{array}$ & $\begin{array}{l}- \\
\text { SSAP2f } \\
\text { SSAP2r }\end{array}$ & $\begin{array}{l}\text { GCTGAATGTGG̈GGATAATTTAT } \\
\text { ATGGCTGCTTCCTTTCGGTTA }\end{array}$ & - & $\begin{array}{c}- \\
641-642\end{array}$ & \\
\hline & & $\begin{array}{l}\text { EphplgroEL(569)F } \\
\text { EphgroEL(1142)R }\end{array}$ & $\begin{array}{c}\text { ATGGTATGCAGTTTGATCGC } \\
\text { TTGAGTACAGCAACACCACCGGAA }\end{array}$ & 54 & 624 & \multirow[b]{2}{*}{ [23] } \\
\hline groEL & A. phagocytophilum & $\begin{array}{l}\text { EphplgroEL(569)F } \\
\text { EphgroEL(1142)R }\end{array}$ & $\begin{array}{c}\text { ATGGTATGCAGTTTGATCGC } \\
\text { TTGAGTACAGCAACACCACCGGAA }\end{array}$ & 54 & $5 \overline{73}$ & \\
\hline groEL & $\begin{array}{l}\text { A. phagocytophilum- } \\
\text { like } \\
1\end{array}$ & $\begin{array}{l}\text { EEGro1F } \\
\text { AnaGroe712R } \\
\text { AnaGroe240F }\end{array}$ & $\begin{array}{c}\text { GAGTTCGACGGTAAGAAGTTCA } \\
\text { ATTAGY *AAGCCTTATGGGTC } \\
\text { CCGCGATCAAACTGCATACC }\end{array}$ & $\begin{array}{l}52 \\
- \\
57\end{array}$ & $\begin{array}{c}670 \\
- \\
432\end{array}$ & [25] \\
\hline
\end{tabular}




\subsection{Sequencing and Phylogenetic Analyses}

Anaplasma phagocytophilum $(n=6)$ and A. phagocytophilum-like $1(n=10)$ positive PCR amplicons were purified using the QIAquick PCR Purification Kit (Qiagen, Hilden, Germany). The purified amplicons were sent to BM Labosis (Ankara, Turkey) for Sanger sequencing to determine DNA sequences of the $16 S$ rRNA gene. Multiple alignments were performed with the CLUSTAL Omega ver. 1.2.1 (https:/ / www.ebi.ac.uk, accessed on 1 February 2019). The representative sequences have been submitted to the GenBank (MT881655 and MT881656 for 16S rRNA gene of A. phagocytophilum-like 1 and A. phagocytophilum, respectively). The sequence alignment was performed using MUSCLE in Geneious prime [25].

Phylogenetic analyses of the $16 \mathrm{~S}$ rRNA sequences obtained in this work and the other sequences submitted to GenBank were carried out. The maximum likelihood analysis (ML) carried out in Mega X [26] was utilized to determine the phylogenetic relationship of the Anaplasma spp. To sequence evolution, best-fit model was assessed as TN93+G+I by using the jModel test v.0.1.1 [27]. Reliability of internal branches of the tree was evaluated by the bootstrapping method with 1000 iterations [28].

\subsection{Statistical Analysis}

Association of the presence of Anaplasma spp. with host species and presence of tick was performed with Epi Info 6.01 (CDC, Atlanta), using the $\chi 2$ test and Fisher's exact test.

\section{Results}

\subsection{Tick Infestation}

Of the 433 small ruminants examined, 190 (43.9\%) were infested with at least one tick species. A total of 1475 adult ticks (449 females, 1026 males) were collected from goats $(1409 / 1475,95.5 \%)$ and sheep $(66 / 1475,4.5 \%)$. Six tick species were identified among all collected ticks. Rhipicephalus bursa $(1269 / 1475,86 \%)$ was the dominant tick species, followed by $R$. turanicus (98/1475, 6.6\%), Dermacentor marginatus (94/1475, 6.4\%), Hyalomma marginatum $(8 / 1475,0.5 \%)$, R. sanguineus s.l. $(5 / 1475,0.3 \%)$, and Ixodes ricinus $(0.06 \%$, only one specimen). The goats were infested with all the identified tick species, whereas sheep were infested with $R$. bursa and R. turanicus.

\subsection{Prevalence and Distribution of Anaplasma spp.}

The prevalence of $A$. phagocytophilum and related variants in sampled goats and sheep is presented in Table 2. Overall, 121/433 (27.9\%) samples collected in studied regions tested positive for Anaplasma spp. by $16 \mathrm{~S}$ rRNA PCR. The infection rate in goats and sheep was determined as $28 \%$ and $27.7 \%$, respectively. RFLP revealed the prevalence of A. phagocytophilum and A. phagocytophilum-like 1 as $1.4 \%$ and $26.5 \%$, respectively. No PCR amplicons derived from goats and sheep were digested by the $B s a$ I enzyme, confirming the absence of Chinese variant (A. phagocytophilum-like 2). Of the 121 positive samples with $16 \mathrm{~S}$ rRNA PCR, 110 (95.6\%) were positive with groEL nested PCR. Six of them $(6 / 110,5.4 \%)$ were positive for A. phagocytophilum and 104 (94.5\%) were positive for A. phagocytophilumlike 1 (Table 2).

Association of the frequency of A. phagocytophilum and A. phagocytophilum-like 1 variant in small ruminants with species and tick infestation is documented in Table 3. The prevalence of Anaplasma spp. was comparable in species, and no difference was detected between infection rates in sheep and goats $(p=0.9603)$. However, the prevalence significantly increased with tick infestation in small ruminants $(p=0.0003)$ (Table 3$)$. 
Table 2. Samples origin, 16S rRNA PCR, RFLP and groEL PCR.

\begin{tabular}{|c|c|c|c|c|c|c|c|c|}
\hline \multirow{2}{*}{$\begin{array}{c}\text { Host } \\
-\end{array}$} & \multirow{2}{*}{$\begin{array}{c}\text { District/Province } \\
-\end{array}$} & \multirow{2}{*}{$\begin{array}{c}\text { 16S rRNA PCR+/No. of Samples } \\
-\end{array}$} & \multicolumn{3}{|c|}{ 16S rRNA PCR + RFLP } & \multirow{2}{*}{ groEL+/16S+ } & \multicolumn{2}{|c|}{ groEL PCR } \\
\hline & & & $\mathrm{AP}$ & AP-like 1 & AP-like 2 & & $\mathrm{AP}$ & AP-like 1 \\
\hline Goat & Akseki/Antalya & $13 / 56(23.2 \%)$ & 2 & 11 & 0 & $12 / 13$ & 2 & 10 \\
\hline- & Manavgat/Antalya & $26 / 111(23.4 \%)$ & 3 & 23 & 0 & $23 / 26$ & 3 & 20 \\
\hline- & Alanya/Antalya & $24 / 55(43.6 \%)$ & 0 & 24 & 0 & $24 / 24$ & & 24 \\
\hline- & Anamur/Mersin & $15 / 44(34.1 \%)$ & 0 & 15 & 0 & $12 / 15$ & & 12 \\
\hline- & Bozyaz1/Mersin & $5 / 30(16.7 \%)$ & 0 & 5 & 0 & $5 / 5$ & & 5 \\
\hline Goat Total & - & $83 / 296(28 \%)$ & 5 & 78 & 0 & $76 / 83(91.5 \%)$ & 5 & 71 \\
\hline- & - & - & - & - & - & - & - & - \\
\hline Sheep & Akseki/Antalya & $5 / 9(55.6 \%)$ & 1 & 4 & 0 & $3 / 5$ & 1 & 2 \\
\hline-1 & Manavgat/Antalya & $18 / 103(17.5 \%)$ & 0 & 18 & 0 & $17 / 18$ & - & 17 \\
\hline- & Alanya/Antalya & $9 / 9(100 \%)$ & 0 & 9 & 0 & $9 / 9$ & - & 9 \\
\hline- & Anamur/Mersin & $6 / 16(37.5 \%)$ & 0 & 6 & 0 & $5 / 6$ & - & 5 \\
\hline Sheep Total & - & $38 / 137(27.7 \%)$ & 1 & 37 & 0 & $34 / 38(89.4 \%)$ & 1 & 33 \\
\hline Grand Total & - & $121 / 433(27.9 \%)$ & $6(1.4 \%)$ & $115(26.5 \%)$ & 0 & $\begin{array}{l}110 / 115 \\
(95.6 \%)\end{array}$ & 6 & 104 \\
\hline
\end{tabular}

Table 3. Association of the frequency (16S rRNA PCR) of Anaplasma phagocytophilum and related variants in small ruminants with species and tick infestation.

\begin{tabular}{cccccc}
\hline & \multicolumn{3}{c}{ Species } & \multicolumn{2}{c}{ Presence of Ticks on the Animals } \\
\cline { 2 - 5 } & $\begin{array}{c}\text { Goats } \\
\boldsymbol{n} \mathbf{( \% )}\end{array}$ & $\begin{array}{c}\text { Sheep } \\
\boldsymbol{n} \mathbf{( \% )}\end{array}$ & $\begin{array}{c}\text { No } \\
\boldsymbol{n} \mathbf{( \% )}\end{array}$ & $\begin{array}{c}\text { Yes } \\
\boldsymbol{n} \mathbf{( \% )}\end{array}$ \\
\hline Number & 296 & 137 & 243 & 190 \\
Positive & $83(28)$ & $38(27.7)$ & $51(20.9)$ & $70(36.8)$ \\
Negative & $213(72)$ & $99(72.3)$ & $192(79.1)$ & $120(63.2)$ \\
\hline$p$-Value & & 0.9603 & \multicolumn{3}{c}{0.0003} \\
\hline
\end{tabular}

\subsection{Molecular and Phylogenetic Analyses}

To validate the RFLP results and identify genetic variants of $A$. phagocytophilumlike 1 , randomly selected 10 representative samples were sequenced. The sequences shared $100 \%$ identity to each other. Therefore, one representative sequence for A. phagocytophilum-like 1 was submitted to the NCBI GenBank database, and deposited with accession number MT881655. This finding indicated that one variant was identified, and named as Aplike1OvineCaprine in this work. BlastN analysis demonstrated that the Aplike1OvineCaprine variant indicated high similarity (99-100\%) to those Anaplasma isolates deposited in the GenBank as uncultured Anaplasma sp. and A. phagocytophilum. Moreover, the Aplike1OvineCaprine variant was $100 \%$ identical to those of A. phagocytophilum-like 1 detected in sheep (Aplike1Ov1, KX702978) and goat (Aplike1GGo2, KM285227) from Tunisia, and cattle from Turkey (Aplike1Bv, MT338494) (Table 4). The A. phagocytophilum Akseki11 Sheep Turkey isolate obtained in this study shared $99.3-99.6 \%$ identity isolated from Niviventer confucianus (A. phagocytophilum ZJ-HGA strain, DQ458805) and human (A. phagocytophilum HZ strain, NR_074113), respectively.

Phylogenetic analysis using the $16 S r R N A$ gene showed that our variant (Aplike1OvineCaprine) clustered a distinct group with those of A. phagocytophilum-like 1 previously published sequences reported in sheep, goats, cattle, deer, and Haemaphysalis ginghaiensis (Figure 2). 
Table 4. Nucleotide differences among 16S rRNA sequences from Anaplasma variants related to A. phagocytophilum (598-599 bp).

\begin{tabular}{|c|c|c|c|c|c|c|c|c|c|c|c|c|c|c|c|c|c|c|}
\hline \multirow{2}{*}{$\begin{array}{c}\text { Host } \\
-\end{array}$} & \multirow{2}{*}{$\begin{array}{c}\text { Genetic Variant }{ }^{\mathrm{a}} \\
-\end{array}$} & \multirow{2}{*}{$\begin{array}{c}\text { Country } \\
-\end{array}$} & \multirow{2}{*}{$\begin{array}{c}\text { GenBank } \\
-\end{array}$} & \multicolumn{14}{|c|}{ Nucleotide Positions ${ }^{b}$} & \multirow{2}{*}{$\begin{array}{c}\text { Reference } \\
-\end{array}$} \\
\hline & & & & 823 & 830 & 1011 & 1109 & 1111 & 1113 & 1120 & 1137 & 1148 & 1237 & 1239 & 1240 & 1260 & 1291 & \\
\hline Human & Webster & USA & NR_044762 & $\mathrm{T}$ & $\mathrm{T}$ & A & G & $\mathrm{T}$ & A & $\mathrm{C}$ & A & $\mathrm{T}$ & $\mathrm{T}$ & $\mathrm{T}$ & $\mathrm{C}$ & G & C & Unpublished \\
\hline Horse & Camawi & USA & AF172167 & $*$ & * & * & * & * & $*$ & * & * & * & * & * & * & * & * & Unpublished \\
\hline $\operatorname{Dog}$ & $\operatorname{Dog} 2$ & USA & СР006618 & * & * & * & * & * & * & * & * & * & * & * & * & * & * & Unpublished \\
\hline Deer & Clone 1 & Japan & JN055357 & $\mathrm{C}$ & * & * & * & $\mathrm{A}$ & - & * & G & C & * & * & * & $*$ & * & [24] \\
\hline Goat & Aplike1GGo1 & Tunisia & KM285226 & C & * & * & * & A & - & * & G & $\mathrm{C}$ & * & * & * & * & * & [7] \\
\hline Goat & Aplike1GGo2 & Tunisia & KM285227 & C & * & * & * & $\mathrm{A}$ & $\mathrm{T}$ & * & G & * & * & * & * & * & * & [7] \\
\hline Sheep & Aplike1GOv1 & Tunisia & KM285230 & C & * & * & * & $\mathrm{A}$ & - & * & G & $\mathrm{C}$ & * & * & * & * & * & [7] \\
\hline Cattle and Goat & Aplike1BvCp1 & Tunisia & KX702974 & $\mathrm{C}$ & * & * & * & A & - & * & $\mathrm{G}$ & $\mathrm{C}$ & * & * & * & * & * & [8] \\
\hline Sheep & Aplike1Ov1 & Tunisia & KX702978 & $\mathrm{C}$ & * & * & * & A & $\mathrm{T}$ & * & G & * & * & * & * & * & * & [8] \\
\hline Sheep and Goat & Aplike2OvCp1 & Tunisia & KX702980 & $\mathrm{C}$ & $\mathrm{A}$ & G & * & A & $\mathrm{T}$ & $\mathrm{T}$ & G & $\mathrm{C}$ & $\mathrm{C}$ & $\mathrm{C}$ & $\mathrm{T}$ & A & $\mathrm{T}$ & [8] \\
\hline Cattle & Aplike1Bv & Turkey & МТ338494 & $\mathrm{C}$ & * & $*$ & * & $\mathrm{A}$ & $\mathrm{T}$ & * & G & * & * & * & * & * & * & Unpublished \\
\hline Sheep and Goat & Aplike1OvineCaprine & Turkey & MT881655 & $\mathrm{C}$ & * & * & * & $\mathrm{A}$ & $\mathrm{T}$ & * & G & * & * & * & * & * & * & Present study \\
\hline Sheep & Aphaakseki11 & Turkey & MT881656 & * & * & * & * & * & * & * & * & * & * & * & $\mathrm{T}$ & * & * & Present study \\
\hline
\end{tabular}

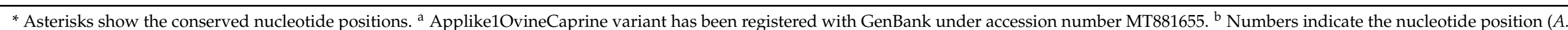

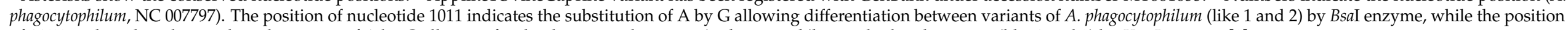
of 1137 nucleotide indicates the substitution of A by G allowing for the distinction between A. phagocytophilum and related variants (like 1 and 2) by XcmI enzyme [8]. 


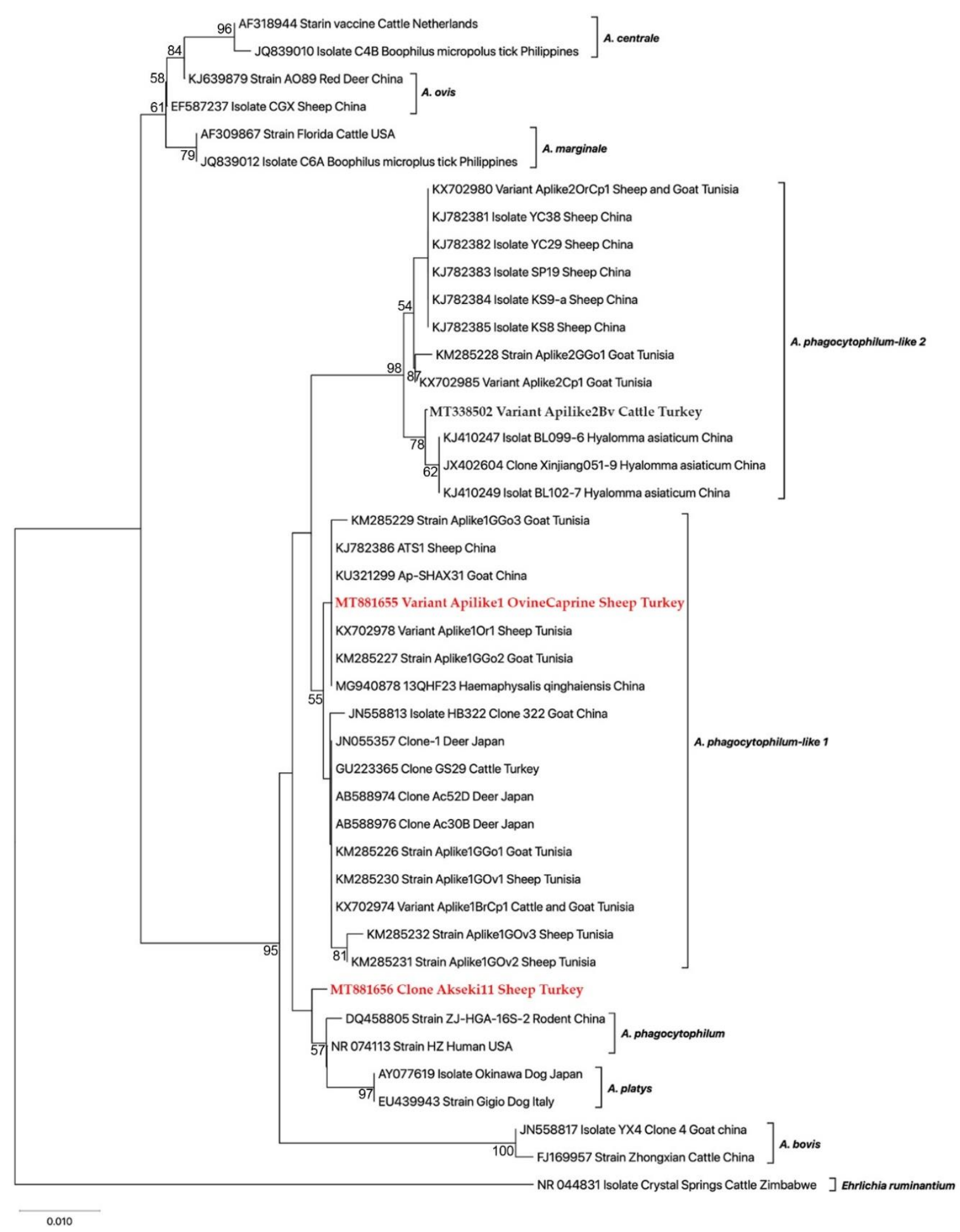

Figure 2. Maximum likelihood phylogenetic tree was inferred with partial sequences (598-599 bp) of the 16S rRNA gene of Anaplasma sp. related to A. phagocytophilum isolated from sheep in Turkey (highlighted in red) with other Anaplasma spp. retrieved from GenBank. Numbers at the nodes refer percentage occurrence in 1000 the bootstrap replication. The new sequences of A. phagocytophilum-like 1 and A. phagocytophilum from this study were highlighted in red. Ehrlichia ruminantium was used as an outgroup. 


\section{Discussion}

Anaplasma phagocytophilum causes tick-borne fever in small ruminants and granulocytic anaplasmosis in horses and dogs [1,2]. It is an emerging tick-borne pathogen for humans as well [3]. The genetic diversity of $A$. phagocytophilum is much greater than expected. Indeed, recent studies have revealed the existence of two distinct Anaplasma species or variants related to A. phagocytophilum, one in Japan and the other in China [11-14,24]. Then, these pathogens were designated as A. phagocytophilum-like 1 and A. phagocytophilum-like 2 variants $[7,8]$. More recently, both genotypes have been documented in ruminants and $R$. turanicus in Tunisia [7,8,17,29], cattle in South Korea [16], and small ruminants in Italy [17]. In the present study, a survey was carried out to detect and identify A. phagocytophilum and $A$. phagocytophilum-like variants in small ruminants from the Mediterranean region of Turkey. Our findings provide molecular evidence for the presence of $A$. phagocytophilum and $A$. phagocytophilum-like 1 in sampled sheep and goats. In the previous studies carried out in Turkey, A. phagocytophilum has been reported in small ruminants $[18,21,30]$. However, this is the first time that $A$. phagocytophilum-like 1 variant in sheep and goats have been reported in the country.

Contrary to A. phagocytophilum, it has been suggested that both Japanese and Chinese variants do not cause clinical infection in ruminants $[8,17]$. In this study, a high prevalence for A. phagocytophilum-like 1 variant was determined (26.5\%), but no clinical infection for tick-borne fever was observed in sheep and goats during sample collection. This result is consistent with the previous suggestions that $A$. phagocytophilum-like variants are considered non-pathogenic for ruminants $[8,16,17]$. The prevalence of $A$. phagocytophilumlike $1(26.5 \%)$ in small ruminants obtained in this study was higher than that observed in Tunisian sheep (7\%) and goats (13.1\%) [8], however, it was lower than that observed in other studies conducted in Mediterranean small ruminants (122/203,60\%) from Tunisia and Italy [17].

It has been previously suggested that serological cross-reactions occur between $A$. phagocytophilum and other Anaplasma species [31,32]. The same situation may be true in some circumstances for molecular markers, for example a pair of primers (SSAP2f/SSAP2r) based on the 16S rRNA gene of A. phagocytophilum were designed for the specific amplification [10]. However, it has been shown that these primers also detect distinct Anaplasma variants related to $A$. phagocytophilum $[7,8,24]$. In this work, the frequency of pathogenic $A$. phagocytophilum was $1.4 \%$, which is not consistent with the previous studies in Turkey that reported values of 66.7\% in Central Anatolia [30] and 19.7\% in Eastern Anatolia [21]. The high infection rates obtained in the previous studies may be due to the selected primers for the amplification of A. phagocytophilum. EE1/EE2 and SSAP2f/SSAP2r primers have been selected to detect A. phagocytophilum in the studies conducted in Central Anatolia [30] and Eastern Anatolia [21], respectively. However, the EE1/EE2 primers are universal for the detection of all Anaplasma spp. including A. phagocytophilum-like variants [33]. It has been also reported that the SSAP2f/SSAP2r can amplify not only A. phagocytophilum, but also $A$. phagocytophilum-like variants $[7,8,24]$. This study provides molecular data for the circulation of A. phagocytophilum and A. phagocytophilum-like 1 Turkish small ruminants. Therefore, cross-reactivity between $A$. phagocytophilum and related variant should be considered in interpreting the findings of surveys to be carried out in the area, where A. phagocytophilum and A. phagocytophilum-like variant co-exist.

As several domestic and wild mammals are hosts or reservoirs for A. phagocytophilum [1,2], abundance and intensity of the tick vector, I. ricinus in Europe including Turkey are considered a major factor affecting the distribution of the pathogen in a specific area. It is well known that there is no I. ricinus in the Eastern and Central Anatolian regions of Turkey [34]. It has been reported that A. phagocytophilum is transmitted by Ixodes spp. (I. persulcatus, I. scapularis and I. ricinus) in some parts of the world including in Europe [1,35]. In Turkey, I. ricinus collected from humans were positive for A. phagocytophilum [5]. So far, data on the transmission of $A$. phagocytophilum-like variants by ticks are lacking. A recent study reported that $R$. turanicus was common in sampled sheep and goats in Tunisia, and 
one $R$. turanicus tick feeding on the goat was found to be infected with A. phagocytophilumlike 2 [28]. In the present study, potential vectors of $A$. phagocytophilum-like 1 was not studied, but we found that the sampled sheep and goats were commonly infested with R. bursa (86\%), R. turanicus (6.6\%), D. marginatus $(6.4 \%)$, and very rarely I. ricinus $(0.06 \%$, only one specimen). Our finding also showed a correlation between Anaplasma positivity and the presence of ticks $(p=0.0003)$, compatible with the finding that the prevalence of A. phagocytophilum-like 1 was higher in goats infested by ticks than in not infested [7]. Based on the abundance of Rhipicepahlus and Dermacentor ticks and the very rarity of $I$. ricinus, we can assume that Rhipicephalus and Dermacentor may play an important role in the transmission of $A$. phagocytophilum-like 1 rather than $I$. ricinus. This assumption is supported by the previous findings that a high prevalence of $A$. phagocytophilum-like variants have been reported in ruminants in the higher semi-arid area of Tunisia, where I. ricinus is not present [8]. However, more detailed studies are needed to validate this assumption and to establish what tick species may play a role in the transmission of $A$. phagocytophilum-like 1 in Turkey.

Our sequencing validated RFLP findings, and showed that the sampled small ruminants were found to be infected with A. phagocytophilum-like 1. Phylogenetic analysis indicated two main separate branches. The Aplike1OvineCaprine (MT881655) variant obtained in this study, as well as those previously reported from sheep, goats, cattle, and ticks, formed a monophylogenic clade distinct from A. phagocytophilum and A. phagocytophilum-like 2, and other members of Anaplasma spp. [7,8,24].

\section{Conclusions}

This work provides molecular data for the circulation of A. phagocytophilum-like 1 for the first time in Turkey. The novel strain is widespread in small ruminants in the Mediterranean area of Turkey with an overall prevalence of $26.5 \%$. This finding revealed that the variant should be considered in the diagnosis of caprine and ovine anaplasmosis.

Author Contributions: Conceptualization, project administration, methodology, validation, formal analysis, investigation, writing-review and editing, M.A.; methodology, validation, formal analysis, S.Ö.; validation, formal analysis, M.C.U. All authors have read and agreed to the published version of the manuscript.

Funding: This work was supported by founding from the Scientific and Technological Research Council of Turkey (TUBITAK) (project no. 1180871).

Institutional Review Board Statement: The study was conducted according to the guidelines of the Declaration of Helsinki and approved by Firat University Animal Experiment Local Ethics Committee (2018/100, 109. 11. 2018).

Data Availability Statement: Data available in a publicly accessible repository.

Acknowledgments: The authors are grateful to Alberto Alberti (University of Sassari, Sassari, Italy) for positive control DNAs from A. phagocytophilum-like variants. We are also thankful to the farmers for their cooperation and the veterinary clinician's Ali Asar for helping with sample collection.

Conflicts of Interest: The authors declare no conflict of interest.

\section{References}

1. Woldehiwet, Z. The natural history of Anaplasma phagocytophilum. Vet. Parasitol. 2010, 167, 108-112. [CrossRef]

2. Stuen, S.; Granquist, E.G.; Silaghi, C. Anaplasma phagocytophilum-a widespread multi-host pathogen with highly adaptive strategies. Front. Cell. Infect. Microbiol. 2013, 3, 31. [CrossRef]

3. Kocan, K.M.; de la Fuente, J.; Cabezas-Cruz, A. The genus Anaplasma: New challenges after reclassification. Rev. Sci. Technol. 2015, 34, 577-586. [CrossRef]

4. Langenwalder, D.B.; Schmidt, S.; Gilli, U.; Pantchev, N.; Ganter, M.; Silaghi, C.; Aardema, M.L.; von Loewenich, F.D. Genetic characterization of Anaplasma phagocytophilum strains from goats (Capra aegagrus hircus) and water buffalo (Bubalus bubalis) by 16S rRNA gene, ankA gene and multilocus sequence typing. Ticks Tick Borne Dis. 2019, 10, 101267. [CrossRef] [PubMed]

5. Aktas, M.; Vatansever, Z.; Altay, K.; Aydin, M.F.; Dumanli, N. Molecular evidence for Anaplasma phagocytophilum in Ixodes ricinus from Turkey. Trans. R. Soc. Trop. Med. Hyg. 2010, 104, 10-15. [CrossRef] [PubMed] 
6. Aktas, M.; Ozubek, S. Bovine anaplasmosis in Turkey: First laboratory confirmed clinical cases caused by Anaplasma phagocytophilum. Vet. Microbiol. 2015, 178, 246-251. [CrossRef]

7. Ben Said, M.; Belkahia, H.; Alberti, A.; Zobba, R.; Bousrih, M.; Yahiaoui, M.; Daaloul-Jedidi, M.; Mamlouk, A.; Gharbi, M.; Messadi, L. Molecular survey of Anaplasma species in small ruminants reveals the presence of novel strains closely related to $A$. phagocytophilum in Tunisia. Vector Borne Zoonotic Dis. 2015, 15, 580-590. [CrossRef]

8. Ben Said, M.; Belkahia, H.; El Mabrouk, N.; Saidani, M.; Ben Hassen, M.; Alberti, A.; Zobba, R.; Bouattour, S.; Bouattour, A.; Messadi, L. Molecular typing and diagnosis of Anaplasma spp. closely related to Anaplasma phagocytophilum in ruminants from Tunisia. Ticks Tick Borne Dis. 2017, 8, 412-422. [CrossRef] [PubMed]

9. Ben Said, M.; Belkahia, H.; Messadi, L. Anaplasma spp. in North Africa: A review on molecular epidemiology, associated risk factors and genetic characteristics. Ticks Tick Borne Dis. 2018, 9, 543-555. [CrossRef] [PubMed]

10. Kawahara, M.; Rikihisa, Y.; Lin, Q.; Isogai, E.; Tahara, K.; Itagaki, A.; Hiramitsu, Y.; Tajima, T. Novel genetic variants of Anaplasma phagocytophilum, Anaplasma bovis, Anaplasma centrale, and a novel Ehrlichia sp. in wild deer and ticks on two major islands in Japan. Appl. Environ. Microbiol. 2006, 72, 1102-1109. [CrossRef]

11. Jilintai, S.N.; Hayakawa, D.; Suzuki, M.; Hata, H.; Kondo, S.; Matsumoto, K.; Yokoyam, N.; Inokuma, H. Molecular survey for Anaplasma bovis and Anaplasma phagocytophilum infection in cattle in pastureland where sika deer appear in Hokkaido, Japan. Jpn. J. Infect. Dis. 2009, 62, 73-75.

12. Ohashi, N.; Inayoshi, M.; Kitamura, K.; Kawamori, F.; Kawaguchi, D.; Nishimura, Y.; Naitou, H.; Hiroi, M.; Masuzawa, T. Anaplasma phagocytophilum-infected ticks, Japan. Emerg. Infect. Dis. 2005, 11, 1780-1783. [CrossRef] [PubMed]

13. Yoshimoto, K.; Matsuyama, Y.; Matsuda, H.; Sakamoto, L.; Matsumoto, K.; Yokoyama, N.; Inokuma, H. Detection of Anaplasma bovis and Anaplasma phagocytophilum DNA from Haemaphysalis megaspinosa in Hokkaido, Japan. Vet. Parasitol. 2010, 168, 170-172. [CrossRef] [PubMed]

14. Kang, Y.J.; Diao, X.N.; Zhao, G.Y.; Chen, M.H.; Xiong, Y.; Shi, M.; Fu, W.M.; Guo, Y.J.; Pan, B.; Chen, X.P.; et al. Extensive diversity of Rickettsiales bacteria in two species of ticks from China and the evolution of the Rickettsiales. BMC Evol. Biol. 2014, 14, 167. [CrossRef]

15. Yang, J.; Li, Y.; Liu, Z.; Liu, J.; Niu, Q.; Ren, Q.; Chen, Z.; Guan, G.; Luo, J.; Yin, H. Molecular detection and characterization of Anaplasma spp. in sheep and cattle from Xinjiang, northwest China. Parasit. Vectors 2015, 19, 108. [CrossRef] [PubMed]

16. Seo, M.G.; Ouh, I.-O.; Kwon, O.-D.; Kwak, D. Molecular detection of Anaplasma phagocytophilum-like Anaplasma spp. and pathogenic A. Phagocytophilum in cattle from South Korea. Mol. Phyl. Evol. 2018, 126, 23-30. [CrossRef]

17. Zobba, R.; Ben Said, M.; Belkahia, H.; Pittaua, M.; Cacciotto, C.; Parpagliaa, M.L.P.; Messadic, L.; Alberto, A. Molecular epidemiology of Anaplasma spp. related to A. phagocytophilum in Mediterranean small ruminants. Acta Tropica. 2020, $202,105286$. [CrossRef]

18. Gokce, H.I.; Genc, O.; Akca, A.; Vatansever, Z.; Unver, A.; Erdogan, H.M. Molecular and serological evidence of Anaplasma phagocytophilum infection of farm animals in the Black Sea Region of Turkey. Acta Vet. Hung. 2008, 56, 281-292. [CrossRef] [PubMed]

19. Aktas, M.; Altay, K.; Ozubek, S.; Dumanli, N. A survey of ixodid ticks feeding on cattle and prevalence of tick-borne pathogens in the BlackSea Region of Turkey. Vet. Parasitol. 2012, 187, 567-571. [CrossRef]

20. Aktas, M. A survey of ixodid tick species and molecular identification of tick-borne pathogens. Vet. Parasitol. 2014, 200, 276-283. [CrossRef]

21. Altay, K.; Dumanli, N.; Aktas, M.; Ozubek, S. Survey of Anaplasma infections in small ruminants from East part of Turkey. Kafkas Univ. Vet. Fak. Derg. 2014, 20, 1-4. [CrossRef]

22. Estrada-Peña, A.; Bouattour, A.; Camicas, J.L.; Walker, A.R. Ticks of Domestic Animals in the Mediterranean Region. A Guide of Identification of Species; University of Zaragoza Press: Zaragoza, Spain, 2004.

23. Alberti, A.; Zobba, R.; Chessa, B.; Addis, M.F.; Sparagano, O.; Pinna Parpaglia, M.L.; Cubeddu, T.; Pintori, G.; Pittau, M. Equine and canine Anaplasma phagocytophilum strains isolated on the island of Sardinia (Italy) are phylogenetically related to pathogenic strains from the United States. Appl. Environ. Microbiol. 2005, 71, 6418-6422. [CrossRef]

24. Ybañez, A.P.; Matsumoto, K.; Kishimoto, T.; Inokuma, H. Molecular analyses of a potentially novel Anaplasma species closely related to Anaplasma phagocytophilum detected in sika deer (Cervus nippon yesoensis) in Japan. Vet. Microbiol. 2012, 157, 232-236. [CrossRef] [PubMed]

25. Edgar, R.C. MUSCLE: A multiple sequence alignment method with reduced time and space complexity. BMC Bioinform. 2004, 5, 113. [CrossRef] [PubMed]

26. Kumar, S.; Stecher, G.; Li, M.; Knyaz, C.; Tamura, K. MEGA X: Molecular Evolutionary Genetics Analysis across computing platforms. Mol. Biol. Evol. 2018, 35, 1547-1549. [CrossRef]

27. Posada, D. jModelTest: Phylogenetic model averaging. Mol. Biol. Evol. 2008, 25, 1253-1256. [CrossRef] [PubMed]

28. Felsenstein, J. Confidence limits on phylogenies: An approach using the bootstrap. Evolution 1985, 39, 783-791. [CrossRef]

29. Belkahia, H.; Ben Said, M.; Ghribi, R.; Selmi, R.; Ben Asker, A.; Yahiaoui, M.; Bousrih, M.; Daaloul-Jedidi, M.; Messadi, L. Molecular detection, genotyping and phylogeny of Anaplasma spp. in Rhipicephalus ticks from Tunisia. Acta Trop. 2019, 191, 38-49. [CrossRef] 
30. Benedicto, B.; Ceylan, O.; Moumouni, P.F.A.; Lee, S.H.; Tumwebaze, M.A.; Li, X.; Galoni, E.M.; Li, Y.; Ji, S.; Ringo, A.; et al. Molecular detection and assessment of risk factors for tick-borne diseases in Sheep and Goats from Turkey. Acta Parasit. 2020, 65, 723-732. [CrossRef] [PubMed]

31. Movilla, R.; García, C.; Siebert, S.; Roura, X. Countrywide serological evaluation of canine prevalence for Anaplasma spp., Borrelia burgdorferi (sensu lato), Dirofilaria immitis and Ehrlichia canis in Mexico. Parasit. Vectors 2016, 9, 421. [CrossRef]

32. Dreher, U.M.; de la Fuente, J.; Hofmann-Lehmann, R.; Meli, M.L.; Pusterla, N.; Kocan, K.M.; Woldehiwet, Z.; Braun, U.; Regula, G.; Staerk, K.D.; et al. Serologic cross-reactivity between Anaplasma marginale and Anaplasma phagocytophilum. Clin. Diagn. Lab. Immunol. 2005, 12, 1177-1183. [CrossRef] [PubMed]

33. Yang, J.; Liu, Z.; Niu, Q.; Liu, J.; Xie, J.; Chen, Q.; Chen, Z.; Guan, G.; Liu, G.; Luo, J.; et al. Evaluation of different nested PCRs for detection of Anaplasma phagocytophilum in ruminants and ticks. BMC Vet. Res. 2016, 12, 35. [CrossRef] [PubMed]

34. Aydin, L.; Bakırc1, S. Geographical distribution of ticks in Turkey. Parasitol. Res. 2007, 101, 163-166. [CrossRef] [PubMed]

35. Sarih, M.; M'ghirbi, Y.; Bouattour, A.; Gern, L.; Baranton, G.; Postic, D. Detection and identification of Ehrlichia spp. in ticks collected in Tunisia andMorocco. J. Clin. Microbiol. 2005, 43, 1127-1132. [CrossRef] [PubMed] 